\title{
Efficiency change and productivity growth in agriculture: A comparative analysis for selected East Asian economies
}

\author{
Yir-Hueih Luh $^{\mathrm{a}, *}$, Ching-Cheng Chang ${ }^{\mathrm{a}, \mathrm{b}}$, Fung-Mey Huang ${ }^{\mathrm{a}}$ \\ a Department of Agricultural Economics, National Taiwan University, Taiwan \\ ${ }^{\mathrm{b}}$ Institute of Economics, Academia Sinica, Taiwan
}

\section{A R T I C L E I N F O}

\section{Article history:}

Received 18 March 2008

Received in revised form 9 May 2008

Accepted 12 May 2008

\section{JEL classification:}

047

057

\section{Keywords:}

East Asian agriculture

International spillovers

Cross-country comparison

\begin{abstract}
A B S T R A C T
This study focuses on identifying the sources of agricultural growth for eight East Asian economies - with special emphasis on factors that can better explain different components of growth. The Malmquist productivity growth index and its two components are calculated and regressed on variables including the human capital endowment, domestic R\&D, international spillovers, and country-specific farming characteristics to characterize the differential patterns of growth. Our empirical evidence suggests that domestic R\&D and its interaction with human capital constitute the major determinant of individual economy's progress in agricultural technology, whereas the human capital endowment is crucial for the catching up effect. Furthermore, for foreign knowledge to contribute to productivity growth either through innovation or through catching up, the host economy has to develop a sufficient learning capacity from education. Countries that do not attempt to develop the learning capability to assimilate and exploit the freely available knowledge may not benefit from international spillovers of agricultural R\&D.
\end{abstract}

(c) 2008 Elsevier Inc. All rights reserved.

\section{Introduction}

In the literature on development, the difference in agricultural productivity across countries is constantly attributed to three general characteristics of supply, namely, the advancement of production technology, the exploitation of scale economies, and the inducement of biased technical change. Recent developments in endogenous growth models stress the importance of human capital and knowledge acquisition (Romer, 1990). However, despite the long and rich history of agricultural productivity analysis, there have not been many studies that sought to identify the endogenous sources of growth in East Asian agriculture.

Among the few, the group of endogenous growth models that succeeded in explaining the growth of the newly industrializing Asian countries (Grossman \& Helpman, 1991; Rivera-Batiz \& Romer, 1991; Romer, 1990) has emphasized the role of international trade. Although those models posit the potential international trade has in increasing specialized inputs, most of the empirical evidence points to the exchange of intangible ideas through different modes of transfer facilitated by bilateral trade. Along with this line of conjecture, the benefits of innovation or R\&D can spill across countries in the form of foreign direct investment, patenting, or international alliances such as joint ventures, and even freely available spillovers that go beyond the geographical boundaries.

By linking foreign direct investment to international spillovers, for instance, Lichtenberg \& Pottelsberghe, 1996 found that although the impacts are not instantaneous, spillovers that go beyond the geographical boundaries have significant impacts

\footnotetext{
* Corresponding author at: Department of Agricultural Economics, National Taiwan University, No. 1., Sec. 4, Roosevelt Road, Taipei, Taiwan. Tel.: +8862 33662651; fax: +886223628496.

E-mail address: yirhueihluh@ntu.edu.tw (Y.-H. Luh).
} 
on growth. Nevertheless, the studies of Aitken and Harrison (1999), Damijan, Majcen, Knell, and Rojec (2001), Djankov and Hoekman (2000), Konings (2001) and Zukowska-Gagelmann (2002) found evidence for the negative spillover effects brought about by the presence of multinationals on the domestic firms' productivity. Coe and Helpman (1993), on the other hand, used trade flows as carriers of international spillovers to find that both domestic and foreign R\&D capital stocks have important effects on total factor productivity. Because foreign R\&D capital stocks are likely to have stronger effects when import flows account for a larger share of GDP, Coe and Helpman's results also suggested that a more open economy will extract larger productivity benefits. By hypothesizing foreign patenting as the channel to transmit, Eaton and Kortum (1996) and Branstetter (2000) found that foreign research stimulates domestic private research, providing empirical support for arguments in favor of international science and technological coordination.

As in any other sectors of the economy, research and extension investments are closely linked to the growth of the agricultural sector. This can be clearly seen from much work that has been devoted to measuring the rates of return on agricultural R\&D. However, the findings in a couple of recent studies suggest the existence of international spillovers as well as its contribution to the agricultural sector (Gutierrez \& Gutierrez, 2003; Johnson \& Evenson, 1999; Schimmelpfennig \& Thirtle, 1999). Therefore, without properly taking into account the effect of international spillovers, previous estimates of rates of return on R\&D may end up overstating the effects of domestic R\&D on agricultural growth. Accordingly, identifying the linkages between international spillovers and the growth of agriculture is important in the sense that it may help explain agricultural growth, and what is more important, it will help characterize the differential patterns of growth in multilateral comparison.

This study focuses on identifying the sources of agricultural growth for eight East Asian economies - China, Indonesia, Japan, Malaysia, the Philippines, South Korea, Thailand and Taiwan. To characterize the differential patterns of growth, the Malmquist productivity growth index and its two components were calculated and regressed on variables including the human capital endowment, domestic R\&D, knowledge spillovers going beyond geographical boundaries, and country-specific farming characteristics. The effects of R\&D spillovers were proxied by constructing an import-weighted sum of trade partners' R\&D stock. This spillover index hypothesizes that a country receives relatively more knowledge spillovers from countries from which it imports relatively more goods and services. In some sense, this proxy variable indicates that the country's capacity to adopt foreign technologies is dependent upon its degree of trade openness. Although the proxy variable is likely to capture only the impact of foreign knowledge channeled through trade flows, it accounts for the impact of international technology spillover based on a major channel of knowledge diffusion exploited in existing research.

The remainder of the paper is organized as follows. In the next section, we briefly introduce the model and the empirical specifications. The data are described in the third section. This is followed by a presentation of the empirical estimates and a discussion of the results, while the final section consists of our conclusions.

\section{Identifying and explaining agricultural growth}

The Malmquist index has gained considerable popularity in recent years due to its appealing feature of allowing a further decomposition of productivity variation. Therefore, to examine the sources of agricultural growth for the eight East Asian economies, we calculate the Malmquist productivity-change indexes as well as the technical-change and efficiency-change components using the mathematical programming procedure outlined in Färe, Grosskopf, Norris, and Zhang (1994). The linkages between the growth of total factor productivity and domestic R\&D as well as international spillovers are identified by regressing the productivity-change indexes and the two components on cumulative R\&D spending.

\subsection{Decomposition of the Malmquist index}

Following Färe et al. (1994), the Malmquist productivity-change index defined as the geometric mean of two distance function-based Malmquist productivity indexes is of the following form,

$M_{0}\left(x^{t+1}, y^{t+1}, x^{t}, y^{t}\right)=\left[\left(\frac{D_{0}^{t}\left(x^{t+1}, y^{t+1}\right)}{D_{0}^{t}\left(x^{t}, y^{t}\right)}\right)\left(\frac{D_{0}^{t+1}\left(x^{t+1}, y^{t+1}\right)}{D_{0}^{t+1}\left(x^{t}, y^{t}\right)}\right)\right]^{1 / 2}$

In the above equation, the first term in the brackets is the Malmquist productivity index with technology in period $t$ as the reference technology. The distance function in the numerator, $D_{0}^{t}\left(x^{t+1}, y^{t+1}\right)$, measures the maximal proportional change in output required to make $\left(x^{t+1}, y^{t+1}\right)$ feasible in relation to the technology in period $t$. $D_{0}^{t}\left(x^{t}, y^{t}\right)$, the distance function in the denominator, measures the reciprocal of the maximum proportional expansion of the output vector $y^{t}$ given input vector $x^{t}$. Similarly, the second term in the brackets represents the Malmquist productivity index with technology in period $t+1$ as the reference technology. The distance function in the denominator, $D_{0}^{t+1}\left(x^{t}, y^{t}\right)$, measures the maximal proportional change in output required to make $\left(x^{t}, y^{t}\right)$ feasible in relation to the technology in period $t+1$, whereas the distance function in the numerator, $D_{0}^{t+1}\left(x^{t+1}, y^{t+1}\right)$, measures the reciprocal of the maximum proportional expansion of the output vector $y^{t+1}$ given $x^{t+1}$. 
The Malmquist productivity-change index in Eq. (1) can be decomposed into the change in relative efficiency and shift in technology over time by rearranging as (Färe, Grosskopf, Lindgren, \& Roos, 1989; Färe, Grosskopf, \& Lovell, 1992)

$M_{0}\left(x^{t+1}, y^{t+1}, x^{t}, y^{t}\right)=\frac{D_{0}^{t+1}\left(x^{t+1}, y^{t+1}\right)}{D_{0}^{t}\left(x^{t}, y^{t}\right)} \times\left[\left(\frac{D_{0}^{t}\left(x^{t+1}, y^{t+1}\right)}{D_{0}^{t+1}\left(x^{t+1}, y^{t+1}\right)}\right)\left(\frac{D_{0}^{t}\left(x^{t}, y^{t}\right)}{D_{0}^{t+1}\left(x^{t}, y^{t}\right)}\right)\right]^{1 / 2}$

The expression outside the brackets illustrates the change in relative efficiency and thus measures the extent to which observed production is getting closer (or farther) from the frontier. For a multilateral analysis, the frontier is a "grand" or "world" frontier, which is constructed by the best practice countries in the sample. The efficiency-change component, therefore, captures the performance relative to the best practice in the sample and can be interpreted as the catching up effect.

The geometric mean of the two ratios inside the brackets in Eq. (2) can be interpreted as the technical-change component, which measures the shift in the frontier over time. Therefore, in our empirical analysis, how much the world frontier shifts at each country's observed input mix is measured by this component. As indicated in Färe et al. (1994), the improvements in this technical-change component can be interpreted as providing evidence of innovation for the country considered. A further examination of this component thus allows us to identify the innovators.

The Malmquist index can be calculated through the linear-programming approach suggested in Färe et al. (1989). Färe et al. (1994) indicate that since for each sample country there is only one aggregate output, the output distance function is equivalent to a frontier production function in the sense that the frontier gives the maximum output given the inputs. The nonparametric programming technique therefore involves constructing a best practice frontier from the data in the sample, and then compares individual countries with the frontier.

To calculate the Malmquist index of productivity change relative to the constant-returns-to-scale technology for country $k^{\prime}$, the linear-programming approach solves for four different distance functions that make up the index, ${ }^{1} 1$. The detailed outlines of the four different linear programming problems can be found in Chang and Luh (2000). with the four output distance functions being the reciprocals of the output-based Farrell measures of technical efficiency. The assumption of constant-returns-to-scale technology can be relaxed by adding the constraint

$\sum_{k=1}^{k} z^{k, t} \leq 1$

The Malmquist productivity-change index in (2) thus can be further decomposed into the change in relative efficiency and shift in technology over time following Ray and Desli (1997) as follows:

$M\left(x^{t+1}, y^{t+1}, x^{t}, y^{t}\right)=[$ technical change $] \times[$ pure efficiency change $] \times[$ scale efficiency change $]$

$$
\begin{aligned}
= & {\left[\left(\frac{D_{v}^{t}\left(x^{t}, y^{t}\right)}{D_{v}^{t+1}\left(x^{t}, y^{t}\right)}\right)\left(\frac{D_{v}^{t}\left(x^{t+1}, y^{t+1}\right)}{D_{v}^{t+1}\left(x^{t+1}, y^{t+1}\right)}\right)\right]^{1 / 2} \times\left[\frac{D_{v}^{t+1}\left(x^{t+1}, y^{t+1}\right)}{D_{v}^{t}\left(x^{t}, y^{t}\right)}\right] } \\
& \times\left[\left(\frac{\mathrm{SE}^{t}\left(x^{t+1}, y^{t+1}\right)}{\mathrm{SE}^{t}\left(x^{t}, y^{t}\right)}\right)\left(\frac{\mathrm{SE}^{t+1}\left(x^{t+1}, y^{t+1}\right)}{\mathrm{SE}^{t+1}\left(x^{t}, y^{t}\right)}\right)\right]^{1 / 2}
\end{aligned}
$$

As suggested in Färe and Grosskopf (1996) and Färe, Grifell-Tatje, Grosskopf, and Lovell (1997), the technical-change component can also be decomposed into the product of a magnitude index and a bias index,

technical change index $=[$ magnitude index $] \times[$ bias index $]=\left[\frac{D_{v}^{t}\left(x^{t}, y^{t}\right)}{D_{v}^{t+1}\left(x^{t}, y^{t}\right)}\right] \times\left[\left(\frac{D_{v}^{t}\left(x^{t+1}, y^{t+1}\right)}{D_{v}^{t+1}\left(x^{t+1}, y^{t+1}\right)}\right)\left(\frac{D_{v}^{t+1}\left(x^{t}, y^{t}\right)}{D_{v}^{t}\left(x^{t}, y^{t}\right)}\right)\right]$,

Furthermore, according to Färe et al. (1997), the bias index in the above equation can be further decomposed as the product of an output and an input-bias index as follows

bias index $=[$ output bias index $] \times[$ input bias index $]$

$$
=\left[\frac{D_{v}^{t}\left(x^{t+1}, y^{t+1}\right)}{D_{v}^{t+1}\left(x^{t+1}, y^{t+1}\right)} \times \frac{D_{v}^{t+1}\left(x^{t+1}, y^{t}\right)}{D_{v}^{t+1}\left(x^{t+1}, y^{t}\right)}\right]^{1 / 2} \times\left[\frac{D_{v}^{t+1}\left(x^{t}, y^{t}\right)}{D_{v}^{t}\left(x^{t}, y^{t}\right)} \times \frac{D_{v}^{t}\left(x^{t+1}, y^{t}\right)}{D_{v}^{t}\left(x^{t+1}, y^{t}\right)}\right]^{1 / 2}
$$

\subsection{Explaining the growth of the agricultural sector}

Assuming that not only traditional labor and capital inputs affect the output level of the agricultural sector, domestic agricultural R\&D capital as well as international spillovers also have a significant impact, our model is similar to that of Coe and Helpman (1993) and Park (1995) and others. The general specification of the aggregate production function, along with 
the expected signs, is as follows:

output $=f(\underset{+}{\operatorname{capital}}, \underset{+}{\text { labor, domestic }} \underset{+}{\mathrm{R} \mathcal{E} \mathrm{D}, \text { international spillovers }})$

To account for possible country-specific factors that might also have systematic impacts on growth in the agricultural sector, we extend the model by incorporating two country-specific variables in the regression. The growth equation frequently used in empirical studies is thus specified as

$\log \mathrm{TFP}_{i t}=\alpha_{0 i}+\alpha_{d} \log \mathrm{SRD}_{i(t-1)}+\alpha_{f} \log \mathrm{IS}_{i(t-1)}+\beta \log \mathrm{SCALE}_{i t}+\gamma \log \mathrm{HCAP}_{i t}$

In the above format, $\log \mathrm{TFP}_{i}$ represents the discrete approximation of the growth rate of total factor productivity. The lagged value of the growth rate of the domestic R\&D stock and international spillovers, in their respective discrete representations, are denoted by $\log \mathrm{SRD}_{i(t-1)}$ and $\log \mathrm{IS}_{i(t-1)}$. The growth coefficient $\alpha_{0 i}$ represents disembodied technological change. The variable SCALE reflects one of the major country-specific agricultural farming characteristics - the land/labor ratio - and is calculated as arable land per unit of agricultural labor. The other country-specific variable, HCAP, is used to quantify the direct influence of improvements in human capital.

The theoretical grounds for the direct influence of human capital on general economic growth have been provided in endogenous growth models such as Romer (1986) and Lucas (1988). For the agricultural sector, however, the emphasis on the education of the labor force or public investment in the form of human capital as a driving force for the growth of productivity can be traced back to the 1960s (Griliches, 1963; Schultz, 1963). More recent studies such as Jamison and Lau (1982) also found that farmers' education was important to productivity enhancement in developing economies such as Thailand, Korea and Malaysia. The study by Nehru and Dhareshwar (1994) further stresses the importance of human capital formation for 83 industrial and developing countries. The comparison of China and India in Bosworth and Collins (2007) reported similar findings in that both China and India have had serious deficiencies in their educational institutions. Therefore, the contribution of improvements in educational attainment to output growth in agriculture, relative to the norm of other East Asian countries whose remarkable growth appears to have been the result of extremely rapid gains in both physical capital and educational attainment, is limited.

Multiplicative dummies are added to our model to make the cross-country comparison. The dummy variables associated with domestic R\&D are used to group sample economies according to their income and size following the classification rule provided by Pardey, Roseboom, and Fan (1998) and Pray and Fuglie (1998). Specifically, $D_{1}=1$ for China, which is classified as large-size and low-income in Pray and Fuglie (1998). $D_{2}=1$ for Malaysia and Thailand, which are classified as middle-income countries in both studies. $D_{3}=1$ for Indonesia and the Philippines, which are classified as medium-size and low-income in both studies. Finally, $D_{4}=1$ for Korea and Taiwan, which are classified as middle-income economies in Pardey et al. (1998). We separate these two countries from the other middle-income group due to geographical considerations. The base group for these four dummy variables is Japan. Another group of dummy variables, $Y_{1}-Y_{7}$, is used to differentiate the country-specific effects of international spillovers. The base group for these seven dummy variables is also Japan.

To infer the existence of international spillovers, a proxy index is constructed in our empirical analysis. The general form of the spillover index can be described as

$\mathrm{IS}_{i}=\sum_{j=1, j \neq i}^{N} \theta_{i j} \mathrm{SRD}_{j}$

where $I S_{i}$ denotes the index of international agricultural R\&D spillovers for the $i$ th country, $\mathrm{SRD}_{j}$ represents the agricultural R\&D stock accumulated by the $j$ th country, and $N$ is the number of its major trade partners. The absorption rate, denoted by $\theta_{i j}$, ranges from zero to one. The absorption rate is the proportion of foreign agricultural R\&D that is spilled over into the country.

Coe and Helpman (1993) and others (Keller, 2000; Lumenga-Neso, Olarrega, \& Schiff, 2001; Xu \& Wang, 1999) constructed a foreign stock of spillovers that is based on the trade flows and the trade partners' R\&D to examine the extent to which a country's productivity level depends on foreign R\&D capital stocks. The foreign R\&D capital stock was calculated as an import-weighted sum of the trade partners' R\&D stock to reflect the possibility that a country receives relatively more knowledge spillovers from countries from which relatively more goods and services are imported. Our spillover index thus defined is calculated as

$\mathrm{IS}_{i}=\sum_{j=1, j \neq i}^{N} s_{i j} \operatorname{SRD}_{j}$

where $s_{i j}$ is the $j$ th country's import share in the $i$ th country's total imports.

\section{Data description}

Our sample includes the agricultural production data for eight East Asian economies: China, Indonesia, Japan, Korea, Malaysia, the Philippines, Taiwan, and Thailand, over the period 1961-2001. The data for China, Indonesia, Japan, Korea, 
Malaysia, the Philippines, and Thailand come from the Food and Agriculture Organization (FAO) of the United Nations' statistical database, which are available through the Internet website: http://www.fao.org. Taiwan's data comes from the Agricultural Yearbook published by the Council of Agriculture, Executive Yuan.

The DEA model comprises one single output and three inputs. We choose the "crop primary" from the FAO database as our output variable. The crop production data reported in the FAO database refer to the actual harvested production from the field or orchard and gardens, excluding harvesting and threshing losses and that part of the crop not harvested for any reason. The unit used for the crop production data is thousand metric tons (1000 $\mathrm{mt})$.

The three input items are land, labor, and fertilizer. Agricultural labor is approximated by the agricultural population, which based on the FAO's definition is all persons depending for their livelihood on agriculture, hunting, fishing or forestry. Agricultural land is the area harvested, and therefore excludes the area from which there was no harvest due to damage, failure, etc. Fertilizer is the quantity of chemical fertilizer consumed in agriculture by the sample country. The unit for fertilizer is also $1000 \mathrm{mt}$.

Our data for agricultural R\&D expenditures is taken from the Agricultural Science and Technology Indicators database. Because the dataset does not include Taiwan and the Philippines, R\&D expenditure for these two countries is calculated based on the average annual agricultural research expenditure provided in Pardey et al. (1998) and the agricultural R\&D intensity in Pray and Fuglie (1998). Except for Taiwan, the import shares for individual economies are taken from the Statistical Yearbook for Asia and the Pacific. External trade data for Taiwan are mainly taken from the Statistical Yearbook of the Republic of China.

Assuming an obsolescence rate of 0.10 , the stock of agricultural R\&D is calculated using the perpetual inventory method suggested in the R\&D Master File, that is,

$\mathrm{SRD}_{t}=(1-\delta) \mathrm{SRD}_{t-1}+\mathrm{RD}_{t}$

where $\mathrm{RD}_{t}$ denotes domestic $\mathrm{R} \& \mathrm{D}$ expenditures at time $t$ and $\delta$ is the obsolescence rate. The initial level of the $\mathrm{R} \& \mathrm{D}$ capital stock is calculated by dividing constant dollar R\&D expenditure by the sum of the rate of obsolescence and the average rate of growth of R\&D expenditure.

Mankiw, Romer, and Weil (1992) has demonstrated that in a neoclassical growth model, the growth of output can be easily derived as a function of changes in the stock of education. Although the endogenous growth theory proposed an alternative view to model output growth as a function of the level of human capital (Lucas, 1988, 1993; Romer, 1990), this paper follows Mankiw et al. (1992) to specify productivity growth as a function of the growth of human capital. Assuming a $6 \%$ depreciation rate and letting the initial level of human capital be proxied by the initial level of gross investment, the stock of the human capital is calculated using the perpetual inventory method as in Eq. (9). The secondary school enrollment is used to proxy the level of gross investment in human capital. Since additional complications in calculating the stock of human capital resulted from the lack of secondary school enrollment data for the agricultural labor force, we took the proportion of secondary school enrollment in total population as a proxy and multiplied it by agricultural labor to measure gross investment in human capital for the agricultural sector. Except for Taiwan, our data for the number of students enrolled in the secondary level schools (including high schools and teacher training) are taken from the "Statistical Yearbook for Asia and the Pacific" published by the United Nations. The data for Taiwan are mostly taken from the "Taiwan Statistical Data Book" published by the Council for Economic Planning and Development of the Republic of China.

Our description of the macroeconomic variables is based on four separate periods, that is, 1961-1970, 1971-1980, 19811990 and 1990-2001. The summary statistics in Table 1 indicate that agricultural production in China, Japan, Indonesia, the Philippines and Thailand increase over the entire time span. However, production in Taiwan, Malaysia, and South Korea experience a downward trend during the fourth period.

Tables 2-4 present the trend of land, labor, and fertilizer use over time. The figures suggest that the area harvested in Taiwan, Japan, and Korea is decreasing over time while an opposite trend is observed for the other five countries. As for agricultural labor, the tables indicate that labor use in China, Indonesia, the Philippines, and Thailand all increase over time,

Table 1

Agricultural production: 1961-1970, 1971-1980, 1981-1990 and 1991-2001 (unit: $1000 \mathrm{mt}^{\mathrm{a}}$ )

\begin{tabular}{|c|c|c|c|c|}
\hline \multirow[t]{2}{*}{ East Asian economies } & \multicolumn{4}{|c|}{ 10-year arithmetic mean } \\
\hline & 1961-1970 & $1971-1980$ & 1981-1990 & 1991-2001 \\
\hline China & 348,662 & 488,885 & 723,572 & $1,054,303$ \\
\hline Japan & 67,246 & 81,360 & 80,540 & 89,108 \\
\hline Korea & 1,476 & 21,069 & 26,826 & 23,267 \\
\hline Taiwan & 18,864 & 21,068 & 18,004 & 14,177 \\
\hline Indonesia & 56,374 & 75,688 & 117,103 & 165,126 \\
\hline Malaysia & 5,910 & 13,936 & 29,801 & 52,575 \\
\hline Philippines & 40,407 & 60,619 & 63,871 & 71,882 \\
\hline Thailand & 24,769 & 51,241 & 82,748 & 114,158 \\
\hline
\end{tabular}

Sources: Calculated from FAO (FAOSTAT database) and Council of Agriculture, Executive Yuan, R.O.C.

a $\mathrm{mt}$ stands for metric tons. 
Table 2

Land in agriculture: 1961-1970, 1971-1980, 1981-1990 and 1991-2001 (unit: 1000 ha $^{\mathrm{a}}$ )

\begin{tabular}{|c|c|c|c|c|}
\hline \multirow[t]{2}{*}{ East Asian economies } & \multicolumn{4}{|c|}{ 10-year arithmetic mean } \\
\hline & $1961-1970$ & $1971-1980$ & 1981-1990 & 1991-2001 \\
\hline China & 135,128 & 138,429 & 142,834 & 156,724 \\
\hline Japan & 7,139 & 5,479 & 4,744 & 4,524 \\
\hline Korea & 3,150 & 3,024 & 2,672 & 2,204 \\
\hline Taiwan & 1,660 & 1,567 & 1,271 & 991 \\
\hline Indonesia & 18,411 & 20,299 & 24,225 & 29,705 \\
\hline Malaysia & 2,527 & 3,497 & 4,333 & 5,346 \\
\hline Philippines & 8,914 & 11,502 & 12,704 & 12,652 \\
\hline Thailand & 9,761 & 13,710 & 17,345 & 17,285 \\
\hline
\end{tabular}

Sources: Calculated from FAO (FAOSTAT database) and Council of Agriculture, Executive Yuan, R.O.C.

a ha stands for hectares.

Table 3

Labor in agriculture: 1961-1970, 1971-1980, 1981-1990 and 1991-2001 (unit: 1000 persons)

\begin{tabular}{|c|c|c|c|c|}
\hline \multirow[t]{2}{*}{ East Asian economies } & \multicolumn{4}{|c|}{ 10-year arithmetic mean } \\
\hline & $1961-1970$ & $1971-1980$ & 1981-1990 & 1991-2001 \\
\hline China & 598,172 & 708,044 & 790,557 & 849,296 \\
\hline Japan & 24,566 & 15,859 & 9,481 & 7,052 \\
\hline Korea & 14,675 & 13,855 & 9,785 & 5,157 \\
\hline Taiwan & 1,743 & 1,575 & 1,223 & 903 \\
\hline Indonesia & 71,813 & 78,234 & 87,507 & 93,637 \\
\hline Malaysia & 5,410 & 5,553 & 5,045 & 4,231 \\
\hline Philippines & 19,320 & 23,285 & 26,630 & 29,104 \\
\hline Thailand & 24,264 & 28,549 & 30,612 & 30,996 \\
\hline
\end{tabular}

Sources: Calculated from FAO (FAOSTAT database) and Council of Agriculture, Executive Yuan, R.O.C.

Table 4

Fertilizers in agriculture: 1961-1970, 1971-1980, 1981-1990, and 1991-2001 (unit: $1000 \mathrm{mt}^{\mathrm{a}}$ )

\begin{tabular}{|c|c|c|c|c|}
\hline \multirow[t]{2}{*}{ East Asian economies } & \multicolumn{4}{|c|}{ 10-year arithmetic mean } \\
\hline & 1961-1970 & 1971-1980 & 1981-1990 & 1991-2001 \\
\hline China & 1,691 & 7,434 & 37,670 & 64,493 \\
\hline Japan & 3,083 & 4,133 & 3,611 & 3,515 \\
\hline Korea & 804 & 1,490 & 1,668 & 1,798 \\
\hline Taiwan & 79 & 1,148 & 1,219 & 1,300 \\
\hline Indonesia & 180 & 1,007 & 3,651 & 4,877 \\
\hline Malaysia & 145 & 435 & 1,333 & 2,295 \\
\hline Philippines & 152 & 409 & 804 & 1,294 \\
\hline Thailand & 92 & 276 & 1,136 & 2,910 \\
\hline
\end{tabular}

Sources: Calculated from FAO (FAOSTAT database) and Council of Agriculture, Executive Yuan, R.O.C.

a $\mathrm{mt}$ stands for metric tons.

with a significant change being observed especially in China. Based on the figures in Table 4, we find that almost all countries increase their fertilizer use over the entire time span.

The statistical grounds on the possible impacts of foreign and domestic agricultural R\&D can be provided by the varying agricultural R\&D intensities and absorptive capacities, as well as the high rate of return on agricultural R\&D. Based on the summary statistics of agricultural R\&D intensities reported in Pardey et al. (1998), it is clear that agricultural R\&D intensities for selected East Asian economies seem to reveal some degree of variation that warrants further investigation of its impact on each economy's growth. The estimates in Thirtle, Lin, and Piesse (2003) further indicate that investment in agricultural R\&D in these economies increases agricultural value added sufficiently leading to high rates of return on agricultural R\&D. Such high rates of return for Asian economies, as noted by Thirtle et al. (2003), may be due to the huge agriculture sectors in countries such as China, and the well-established national agricultural research systems in those other economies. The descriptive statistics for each economy's absorptive capability ${ }^{2} 2$. Each economy's absorptive capability of foreign R\&D spillovers was calculated by the foreign economy's import share to reflect the possibility that a country receives relatively more knowledge spillovers from countries from which relatively more goods and services are imported. Descriptive statistics of each economy's absorptive capability is available from the authors upon request. provide further evidence that international spillovers might be an important determinant of productivity growth in the eight East Asian economies. The figures indicate not only that each economy's absorptive capability of the foreign economy's agricultural R\&D changes with time, but some of the economies' major trading partners also experience a change in role play. 


\section{Results and discussion}

The geometric means of the Malmquist productivity-change indexes and the two components of growth for each sample economy over every 10-year period are listed in Table 5. To take into account possible structural change, preliminary graphical diagnosis and Chow tests are performed to examine the differential growth patterns of the eight East Asian economies. The scatter diagrams in Fig. 1 demonstrate the time trend of the productivity-change indexes and the two components of growth. Three different growth patterns are observed for the eight East Asian economies. Group I that exhibits similar growth patterns consists of Thailand, the Philippines and Indonesia. As noted by Färe et al. (1994), improvements in either productivity or any of the two components are associated with values exceeding unity, while values less than unity denote a regression or deterioration in performance. Therefore, it is clear from the time trend of the productivity-change indexes that the productivity of these three economies experienced deterioration in the early periods and then gradually leveled off. If we take a deeper look at the two components of productivity change, we can find that these three economies experienced productivity deterioration and technical progress at the same time. Therefore, although Thailand, the Philippines and Indonesia all exhibited efficiency improvements over time, especially for Thailand and the Philippines during the last 20 years, agricultural productivity in these three economies has deteriorated because technical regression has had a dominating effect on the improvement in efficiency.

The group contrasting with group I includes Malaysia and Japan. For these two economies, we observe obvious improvements in productivity over time. The reason for such improvements can be well summed up by the consistent technical progress and improvement in efficiency over the entire time span. This result demonstrates that among the eight East Asian economies, both Japan and Malaysia can be innovative and efficient at the same time. The remaining three economies - China, Korea and Taiwan - exhibit a different pattern of productivity change. The productivity-change index for these three economies does not reveal either an upper trend as in Japan and Malaysia, or a downward trend as in Thailand, the Philippines and Indonesia. By further looking at these two components of productivity change, we find that Taiwan consistently remained on the frontier over the entire time span, and the fluctuation in productivity change therefore depends mostly on the technical-change component. Because that component does not exhibit much variation, we did not find obvious growth or deterioration in Taiwan's agricultural productivity. As for China and Korea, they experience fluctuations in either the technical-change or efficiency-change components, which eventually lead to a similar pattern of productivity growth for these two economies.

Table 5

Decomposition of the Malmquist productivity-change index

\begin{tabular}{|c|c|c|c|c|}
\hline \multirow[t]{2}{*}{ East Asian economies } & \multicolumn{4}{|c|}{ Malmquist index } \\
\hline & $1961-1970$ & $1971-1980$ & $1981-1990$ & $1991-2001$ \\
\hline China & 0.826 & 1.003 & 0.982 & 1.021 \\
\hline Japan & 1.032 & 1.027 & 1.013 & 1.023 \\
\hline Korea & 1.033 & 1.010 & 0.992 & 1.022 \\
\hline Taiwan & 1.012 & 1.000 & 0.989 & 1.014 \\
\hline Indonesia & 0.973 & 0.995 & 1.008 & 1.020 \\
\hline Malaysia & 1.035 & 1.068 & 1.001 & 1.057 \\
\hline Philippines & 0.992 & 0.999 & 0.984 & 0.984 \\
\hline Thailand & 0.981 & 1.037 & 0.952 & 1.000 \\
\hline \multirow[t]{2}{*}{ East Asian economies } & \multicolumn{4}{|c|}{ Technical-change component } \\
\hline & 1961-1970 & 1971-1980 & $1981-1990$ & $1991-2001$ \\
\hline China & 0.904 & 1.001 & 1.001 & 1.011 \\
\hline Japan & 1.013 & 1.025 & 1.013 & 1.023 \\
\hline Korea & 1.012 & 1.004 & 1.002 & 1.007 \\
\hline Taiwan & 1.012 & 1.000 & 0.989 & 1.017 \\
\hline Indonesia & 0.978 & 1.011 & 0.998 & 1.003 \\
\hline Malaysia & 1.014 & 1.005 & 1.013 & 1.039 \\
\hline Philippines & 0.992 & 0.999 & 0.984 & 0.984 \\
\hline Thailand & 0.959 & 1.035 & 0.951 & 0.998 \\
\hline \multirow[t]{2}{*}{ East Asian economies } & \multicolumn{4}{|c|}{ Efficiency-change component } \\
\hline & $1961-1970$ & $1971-1980$ & $1981-1990$ & $1991-2001$ \\
\hline China & 0.967 & 1.016 & 0.984 & 1.013 \\
\hline Japan & 1.024 & 1.002 & 1.000 & 1.000 \\
\hline Korea & 1.024 & 1.013 & 0.991 & 1.017 \\
\hline Taiwan & 1.000 & 1.000 & 1.000 & 0.997 \\
\hline Indonesia & 0.991 & 1.001 & 1.015 & 1.020 \\
\hline Malaysia & 1.024 & 1.064 & 0.988 & 1.019 \\
\hline Philippines & 1.000 & 1.000 & 1.000 & 1.000 \\
\hline Thailand & 1.031 & 1.004 & 1.000 & 1.000 \\
\hline
\end{tabular}


a. Thailand

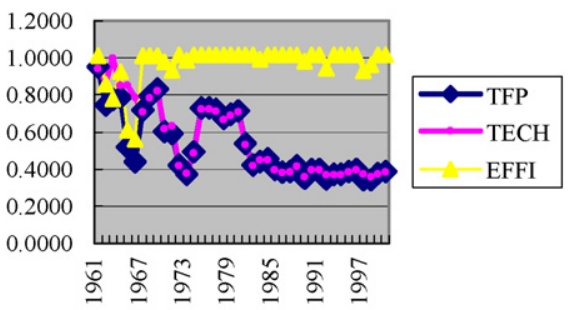

c. Philippines

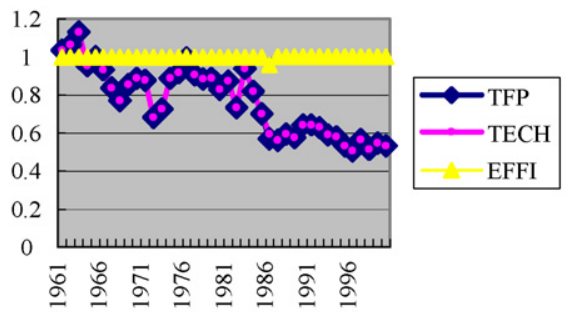

e. Korea

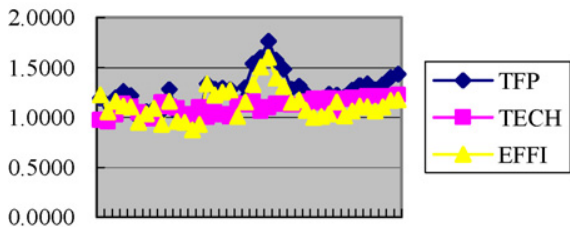

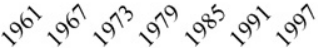

g. Indonesia

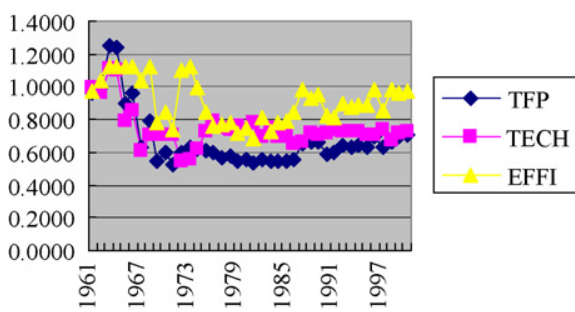

b. Taiwan

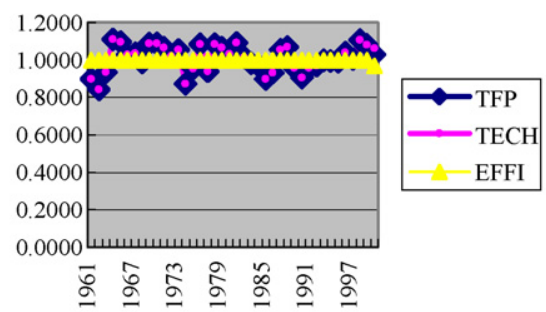

d. Malaysia

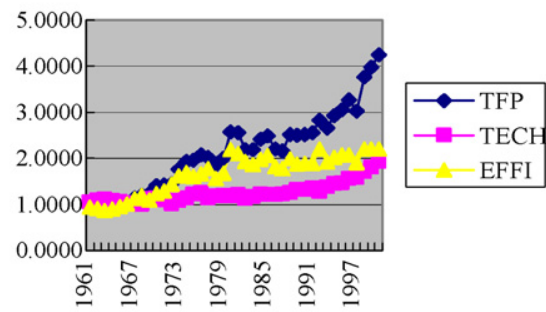

f. Japan

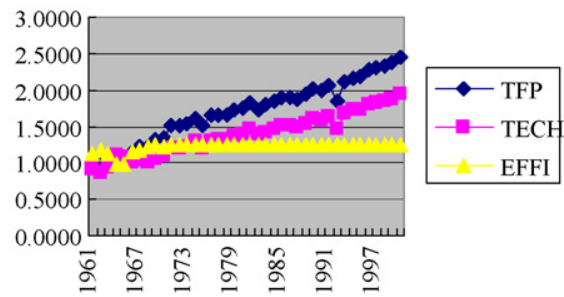

h. China

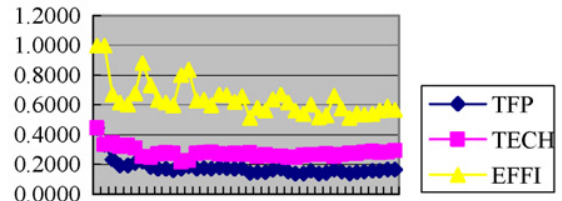

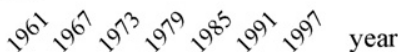

Fig. 1. Scatter diagram of the Malmquist TFP index and the two components.

The previous discussion, however, is based on a preliminary graphical analysis. Since it is common for data involving long time series to exhibit structural change in the relationship between the explanatory and dependent variables, we apply the Chow tests to the 40-year data to examine whether structural change does take place in each sample economy. According to our graphical diagnosis, the group I economies experienced productivity deterioration in the early periods but then gradually leveled off. Therefore, for those three economies, the point of the structural break is specified in the year 1969 for Indonesia, the year 1986 for the Philippines, and the year 1982 for Thailand. The year 1980 is specified as the break point for the remaining five economies. Table 6 reports the results of the Chow test. The test results indicate that, except for Taiwan, most of the East Asian economies experienced structural change over the period 1961-2001.

In order to give a more detailed delineation of the differences and similarities in the growth patterns for the sample economies, further decomposition results of efficiency change and technical change over every 10-year period are reported in Tables 7 and 8. In comparison, Korea has the lowest scale efficiency among all the sample economies. Since the deterioration in productivity in Korea is mainly due to efficiency loss, it is a reasonable conjecture that the source of efficiency loss is the scale component. Our results also suggest that, with only very few exceptions, almost all East Asian economies achieve pure efficiency improvements over the entire time span. 
Table 6

Results of the Chow test

\begin{tabular}{|c|c|c|c|c|}
\hline Economy & $e_{p}^{\prime} e_{p}$ & $e_{1}^{\prime} e_{1}$ & $e_{2}^{\prime} e_{2}$ & $F$-test $^{\mathrm{a}}$ \\
\hline Taiwan $^{\mathrm{b}}$ & $0.18790380($ d.f. $=37)$ & $0.10979920($ d.f. $=16)$ & $0.0553($ d.f. $=18)$ & 1.562022144 \\
\hline Philippines $^{c}$ & $0.30043780($ d.f. $=37)$ & $0.15821340($ d.f. $=22)$ & 0.0181 (d.f. $=12$ ) & 7.982298665 \\
\hline Koreab $^{\mathrm{b}}$ & $0.89508120($ d.f. $=37)$ & $0.30489080($ d.f. $=16)$ & 0.29281 (d.f. $=18)$ & 5.638895414 \\
\hline Indonesia $^{\mathrm{d}}$ & $0.83892110($ d.f. $=37)$ & $0.13586000($ d.f. $=6)$ & 0.0402 (d.f. $=28)$ & 42.667353827 \\
\hline Thailand $^{\mathrm{e}}$ & $0.52741680($ d.f. $=37)$ & $0.39320920($ d.f. $=18)$ & 0.0109 (d.f. = 16) & 3.459476786 \\
\hline Malaysiab $^{\mathrm{b}}$ & $3.94497700($ d.f. $=37)$ & $0.23765860($ d.f. $=16)$ & 2.79991 (d.f. = 18) & 3.385614225 \\
\hline Japan $^{\text {b }}$ & $0.20990180($ d.f. $=37)$ & $0.06605973($ d.f. $=16)$ & 0.0610 (d.f. $=18)$ & 7.385860989 \\
\hline China $^{\mathrm{b}}$ & $0.05654271($ d.f. $=37)$ & 0.03898859 (d.f. $=16)$ & 0.00245 (d.f. $=18)$ & 4.131647014 \\
\hline
\end{tabular}

a The $F$-statistics are calculated as $F=\left[e_{p}^{\prime} e_{p}-\left(e_{1}^{\prime} e_{1}+e_{2}^{\prime} e_{2}\right) / k\right] /\left[\left(e_{1}^{\prime} e_{1}+e_{2}^{\prime} e_{2}\right) /\left(n_{1}+n_{2}-2 k\right)\right]$

b Break point specified in the year 1980 .

c Break point specified in the year 1986 .

d Break point specified in the year 1969 .

e Break point specified in the year 1982 .

Following Färe and Grosskopf (1996) and Färe et al. (1997), for the one-output case as in our model, the technical-change index can be decomposed into the product of a magnitude index and an input-bias index. From Table 8, we can find that the major source of technical regress for most economies is the deterioration in magnitude. The magnitude of this technical regress may provide a reasonable explanation for the deterioration in agricultural productivity experienced by the Philippines and Thailand over the entire time span. The case of Taiwan is slightly different in that, despite its input efficiency being the highest among all sample economies, the magnitude of its efficiency is also the lowest. Therefore, the first priority for the economy would be to expand the production scale to improve the productivity loss associated with the magnitude of the technical regress. According to Färe, Grosskopf, and Norris (1997), under conditions such as constant-returns-to-scale technology and implicit Hicksian input-neutral technical change, input bias will not contribute to productivity change. The results in Table 8 further imply that, for most East Asian economies, input bias contributes positively to the performance of the agricultural sector in the form of technical progress. However, constant returns to scale and Hicksian neutral technical change seem to characterize Korean agriculture.

Our previous discussions focus on identifying which effect - catching up or technical change - is the major source of productivity growth in the agricultural sectors of the eight East Asian economies. To further explain the differential patterns of growth observed in the region, we explore the implications of our results by incorporating the human capital endowment, domestic R\&D, international spillovers, and country-specific farming characteristics into the model. The system of equations estimated includes three dependent variables, the Malmquist productivity-change index, the technical-change component, and the efficiency improvement component. Since the seemingly unrelated regression (SUR) model allows for crossequation correlations, it fits into our panel data structure.

The results of the SUR analysis are reported in Table 9. With Japan as the base group, multiplicative dummy variables allow us to obtain both country-specific coefficients for international spillovers and region-specific coefficients for domestic

Table 7

Decomposition of the efficiency-change component

\begin{tabular}{|c|c|c|c|c|}
\hline \multirow[t]{2}{*}{ East Asian economies } & \multicolumn{4}{|c|}{ Scale efficiency } \\
\hline & 1961-1970 & 1971-1980 & 1981-1990 & 1991-2001 \\
\hline China & 0.967 & 1.016 & 0.984 & 1.013 \\
\hline Japan & 1.024 & 1.002 & 1.000 & 1.000 \\
\hline Korea & 1.004 & 0.987 & 0.995 & 0.983 \\
\hline Taiwan & 1.000 & 1.000 & 1.000 & 0.997 \\
\hline Indonesia & 0.994 & 1.002 & 0.996 & 1.020 \\
\hline Malaysia & 1.024 & 1.064 & 0.986 & 1.017 \\
\hline Philippines & 1.000 & 1.000 & 1.000 & 1.000 \\
\hline Thailand & 1.001 & 1.004 & 1.000 & 1.001 \\
\hline \multirow[t]{2}{*}{ East Asian economies } & \multicolumn{4}{|c|}{ Pure efficiency } \\
\hline & 1961-1970 & 1971-1980 & $1981-1990$ & 1991-2001 \\
\hline China & 1.000 & 1.000 & 1.000 & 1.000 \\
\hline Japan & 1.000 & 1.000 & 1.000 & 1.000 \\
\hline Korea & 1.034 & 1.027 & 0.997 & 1.043 \\
\hline Taiwan & 1.000 & 1.000 & 1.000 & 1.000 \\
\hline Indonesia & 0.995 & 0.993 & 1.018 & 1.000 \\
\hline Malaysia & 1.000 & 1.000 & 1.001 & 1.001 \\
\hline Philippines & 1.000 & 1.000 & 1.000 & 1.000 \\
\hline Thailand & 1.030 & 1.000 & 1.000 & 1.000 \\
\hline
\end{tabular}


Table 8

Decomposition of the technical-change component

\begin{tabular}{|c|c|c|c|c|}
\hline \multirow[t]{2}{*}{ East Asian economies } & \multicolumn{4}{|c|}{ Magnitude component } \\
\hline & $1961-1970$ & $1971-1980$ & 1981-1990 & 1991-2001 \\
\hline China & 0.874 & 0.996 & 1.002 & 1.010 \\
\hline Japan & 1.012 & 0.994 & 0.997 & 1.000 \\
\hline Korea & 1.012 & 1.003 & 1.003 & 1.007 \\
\hline Taiwan & 0.970 & 0.966 & 0.956 & 1.009 \\
\hline Indonesia & 0.938 & 1.025 & 0.998 & 1.004 \\
\hline Malaysia & 1.013 & 1.005 & 1.013 & 1.033 \\
\hline Philippines & 0.939 & 0.946 & 0.934 & 0.948 \\
\hline Thailand & 0.944 & 1.001 & 0.900 & 0.992 \\
\hline \multirow[t]{2}{*}{ East Asian economies } & \multicolumn{4}{|c|}{ Input-bias component } \\
\hline & 1961-1970 & 1971-1980 & 1981-1990 & 1991-2001 \\
\hline China & 1.121 & 1.006 & 0.999 & 1.002 \\
\hline Japan & 1.001 & 1.031 & 1.016 & 1.023 \\
\hline Korea & 1.000 & 1.002 & 1.000 & 1.000 \\
\hline Taiwan & 1.045 & 1.039 & 1.034 & 1.008 \\
\hline Indonesia & 1.051 & 0.985 & 1.000 & 0.998 \\
\hline Malaysia & 1.001 & 1.000 & 1.000 & 1.006 \\
\hline Philippines & 1.060 & 1.060 & 1.054 & 1.037 \\
\hline Thailand & 1.022 & 1.032 & 1.073 & 1.006 \\
\hline
\end{tabular}

R\&D. The results in Table 9 suggest that, for most East Asian economies, domestic R\&D is an important determinant of the growth in the agricultural sector, whereas foreign R\&D channeled through trade does not contribute significantly to the growth of the agricultural sector. However, most of the interaction terms for spillover and human capital have significant coefficients and, therefore, our results provide empirical evidence that the flow of advanced technology going beyond the geographic boundaries can promote growth only through advances in education levels.

Further regression analyses where the dependent variables are the two components of total factor productivity, i.e., technical progress and efficiency change, respectively, yield some interesting empirical implications. First of all, results in Table 9 demonstrate that domestic R\&D and its interaction with human capital constitute the major determinant for the individual economy's progress in agricultural technology. This seems to be in accordance with the general expectation that although the generation of new technology comes from investment in R\&D, to have the newly developed technology to take effect may involve investments in human capital (Antle \& Capalbo, 1988). Furthermore, the results obviously reveal the importance of human capital in the catching up effect. As emphasized by the endogenous growth theory, human capital includes knowledge, experience and skills possessed by workers involved in the production process. Therefore, a welltrained or well-educated worker will be in a better position to be adaptive to changing technologies and to make necessary adjustments, which eventually will lead to more efficient production. Our results confirm the projections of the theory.

Our last implication from the component regression is that by combining the results from explaining the movement in both components, we found that foreign knowledge alone does not play an important part in promoting the East Asian economy's technological progress or efficiency change. That is, for foreign knowledge to contribute to productivity growth either through innovation or through catching up, the host economy has to develop a sufficient learning capacity from education. This argument can be further elaborated by looking at the unique character of agricultural technology. As noted by Hayami (1997), Sachs (2001), and Gutierrez and Gutierrez (2003), the transfer of agricultural technology beyond the geographical boundaries is more difficult than the transfer of industrial technology. Countries that do not attempt to develop the learning capability to assimilate and exploit the freely available knowledge may not benefit from international spillovers of agricultural R\&D.

\section{Concluding remarks}

This study focuses on identifying the sources of agricultural growth for eight East Asian economies. Three different growth patterns are observed for the sample economies. First of all, the productivity of Thailand, the Philippines and Indonesia experienced deterioration in the early periods and then gradually leveled off. Although the three economies all exhibited efficiency improvements over time, agricultural productivity had deteriorated because technical regress had a dominating effect on the improvement in efficiency. Contrary to the previous case, Japan and Malaysia exhibited obvious improvements in productivity over time, and the reason for such improvements may be due to consistent technical progress and efficiency improvement over the entire time span. For economies such as China, Korea and Taiwan, the productivitychange index does not reveal either an upward or downward trend. A further look at the two components in productivity change suggest that the fluctuation of productivity change depends mostly on either the technical-change or efficiencychange component, which did not exhibit much variation over the entire time span. 
Table 9

Results of the SUR estimation

\begin{tabular}{|c|c|c|c|}
\hline Variables & TFP & $\mathrm{TECH}$ & EFFI \\
\hline Intercept & $20.921(14.33)$ & $-0.446(12.89)$ & $15.119(30.38)^{* *}$ \\
\hline Year & $-0.010(0.0 .007)$ & $0.0008(0.01)$ & $-0.007(0.25)^{* *}$ \\
\hline Land/labor ratio & $-0.241(0.289)$ & $-0.4196(0.26)$ & $0.2398(0.18)$ \\
\hline \multicolumn{4}{|l|}{ Domestic R\&D } \\
\hline Japan & $0.449(0.224)^{* *}$ & $0.3893(0.21)^{*}$ & - \\
\hline D1 vs. Japan & $-0.845(0.403)^{* *}$ & $-0.6955(0.37)^{*}$ & - \\
\hline D2 vs. Japan & $-0.520(0.229)^{* *}$ & $-0.4597(0.21)^{* *}$ & - \\
\hline D3 vs. Japan & $-0.460(0.224)^{* *}$ & $-0.4006(0.21)^{*}$ & - \\
\hline D4 vs. Japan & $-0.479(0.332)$ & $-0.5840(0.30)^{*}$ & - \\
\hline \multicolumn{4}{|l|}{ RD $\times$ HUM_K } \\
\hline Japan & $-0.021(0.010)^{* *}$ & $-0.0182(3.46)^{* *}$ & - \\
\hline D1 vs. Japan & $0.022(0.010)^{* *}$ & $0.0186(0.009)^{* *}$ & - \\
\hline D2 vs. Japan & $0.044(0.016)^{* *}$ & $0.0424(0.015)^{* *}$ & - \\
\hline D3 vs. Japan & $0.0205(0.010)^{* *}$ & $0.0182(0.009)^{* *}$ & - \\
\hline D4 vs. Japan & $0.025(0.025)$ & $0.0384(0.022)^{*}$ & - \\
\hline Human_Capital & $0.003(0.004)$ & $0.0031(0.003)$ & - \\
\hline Japan & - & - & $0.0052(0.002)^{* *}$ \\
\hline China vs. Japan & - & - & $-0.0058(0.002)^{* *}$ \\
\hline Korea vs. Japan & - & - & $-0.0020(0.004)$ \\
\hline Indo. vs. Japan & - & - & $-0.0110(0.004)^{* *}$ \\
\hline Malay. vs. Japan & - & - & $0.0626(0.027)^{* *}$ \\
\hline Phi. vs. Japan & - & - & $0.0034(0.007)$ \\
\hline Taiwan vs. Japan & - & - & $0.0237(0.013)^{*}$ \\
\hline Thai. vs. Japan & - & - & $-0.0011(0.011)$ \\
\hline \multicolumn{4}{|l|}{ Spillover } \\
\hline Japan & $-0.005(0.052)$ & $-0.0048(0.048)$ & - \\
\hline China vs. Japan & $0.158(0.146)$ & $0.1342(0.133)$ & - \\
\hline Korea vs. Japan & $-0.085(0.076)$ & $-0.0038(0.070)$ & - \\
\hline Indo. vs. Japan & $-0.029(0.063)$ & $0.0200(0.058)$ & - \\
\hline Malay. vs. Japan & $-0.123(0.071)^{*}$ & $-0.0905(0.064)$ & - \\
\hline Phi. vs. Japan & $0.048(0.059)$ & $0.0784(0.054)$ & - \\
\hline Taiwan vs. Japan & $-0.016(0.157)$ & $0.0174(0.144)$ & - \\
\hline Thai. vs. Japan & $0.081(0.073)$ & $0.1110(0.067)^{*}$ & - \\
\hline \multicolumn{4}{|l|}{ SPILL $\times$ HUM_K } \\
\hline Japan & $0.00012(0.0001)^{*}$ & $0.00004(0.0001)$ & $0.00009(0.00005)^{*}$ \\
\hline China vs. Japan & $-0.00030(0.0003)$ & $-0.00033(0.0003)$ & $0.00010(0.00005)^{*}$ \\
\hline Korea vs. Japan & $0.00641(0.0039)^{*}$ & $0.00053(0.0035)$ & $0.00027(0.00037)$ \\
\hline Indo. vs. Japan & $0.00258(0.0023)$ & $-0.00052(0.0021)$ & $0.00162(0.00065)^{* *}$ \\
\hline Malay. vs. Japan & $0.03534(0.0104)^{* *}$ & $0.01792(0.0093)^{*}$ & $0.00056(0.00432)$ \\
\hline Phi. vs. Japan & $-0.00508(0.0023)^{* *}$ & $-0.00811(0.0020)^{* *}$ & $0.00038(0.00142)$ \\
\hline Taiwan vs. Japan & $0.00956(0.0344)$ & $0.00324(0.0316)$ & $0.00069(0.00362)$ \\
\hline Thai vs. Japan & $-0.01540(0.0057)^{* *}$ & $-0.01865(0.0053)^{* *}$ & $0.00048(0.00174)$ \\
\hline
\end{tabular}

System weighted $R$-square is 0.8463 with 350 degrees of freedom.

* Denotes significant at the 0.05 significance level.

** Denotes significant at the 0.01 significance level.

Further decomposition results of efficiency change and technical change indicate that, with only very few exceptions, almost all East Asian agriculture achieves pure efficiency improvements over the entire time span, while input bias contributes positively to the performance of the agricultural sector in the form of technical progress. However, the major source of technical regress for most economies is the deterioration in magnitude. This magnitude of the technical regress provides a reasonable explanation for the deterioration in agricultural productivity experienced by the Philippines and Thailand.

To further explain the differential patterns of growth observed in the region, we explore the implications of our results by incorporating the human capital endowment, domestic R\&D, international spillovers, and country-specific farming characteristics into the model. The results suggest that, for most East Asian economies, domestic R\&D is an important determinant of the growth of the agricultural sector, whereas international R\&D spillovers can promote growth only through advances in education levels.

Our work departs from the previous literature by identifying factors that can better explain the two components of productivity growth. Our empirical evidence suggests that domestic R\&D and its interaction with human capital constitute the major determinant of an individual economy's progress in agricultural technology, which is in accordance with the general expectation that, although the generation of new technology comes from investment in R\&D, to have the newly developed technology take effect may involve investments in human capital. On the other hand, our results also suggest that human capital is the major determinant of the catching up effect. A well-trained or well-educated worker is in a better 
position to be adaptive to changing technologies and to make necessary adjustments, which will eventually lead to more efficient production.

One of the important implications of the component regression is that foreign R\&D alone does not play an important part in promoting the East Asian economies' technological progress or efficiency change. That is, for foreign knowledge to contribute to productivity growth either through innovation or through catching up, the host economy has to develop a sufficient learning capacity from education. This observation confirms the previous argument that the transfer of agricultural technology beyond the geographical boundaries is more difficult than the transfer of industrial technology (Gutierrez \& Gutierrez, 2003; Hayami, 1997; Sachs, 2001). That is, countries that do not attempt to develop the learning capability to assimilate and exploit the freely available knowledge may not benefit from international spillovers of agricultural R\&D.

This paper is subject to limitations and there remain a couple of ways in which the analysis can be extended and generalized. In the present setting, the effects of foreign R\&D spillovers are assumed to be channeled through international trade. The spillover index constructed in this study thus tends to embody a major component of the whole process of international knowledge spillovers. Consequently, our empirical results ought to be interpreted with caution.

\section{Acknowledgement}

Part of this research was supported by the National Science Council in the Republic of China under project number NSC902415-H-007-005.

\section{References}

Aitken, B. J., \& Harrison, A. E. (1999). Do domestic firms benefit from direct foreign investment? American Economic Review, 89, $605-618$.

Antle, J., \& Capalbo, S. (1988). An introduction to recent developments in production theory and productivity measurement. In S. Capalbo \& J. Antle (Eds.), Agricultural productivity measurement and explanation. Washington, DC: Resources for the Future.

Bosworth, B., \& Collins, S. M. (2007). Accounting for growth: Comparing China and India (NBER Working Paper Series, No. 12943).

Branstetter, L. G. (2000). Is foreign direct investment a channel of knowledge spillovers? Evidence from Japan's FDI in the United States (NBER Working Paper Series, No. 8015).

Chang, C. C., \& Luh, Y.-H. (2000). Efficiency change and the growth in productivity: the Asian growth experience. Journal of Asian Economics, 10(4), 551-570.

Coe, D. T., \& Helpman, E. (1993). International RED spillovers (NBER Working Paper Series, No. 4444).

Damijan, J. P., Majcen, B., Knell, M., \& Rojec, M. (2001). The role of FDI, absorptive capacity and trade in transferring technology to transition countries: Evidence from firm panel data for eight transition countries, Mimeo, UN Economic Commission for Europe, Geneva.

Djankov, S., \& Hoekman, B. (2000). Foreign investment and productivity growth in Czech enterprises. World Bank Economic Review, $14,49-64$.

Eaton, J., \& Kortum, S. (1996). Measuring technology diffusion and the international sources of growth. Eastern Economic Journal, 22, 401-410.

Färe, R., Grifell-Tatje, E., Grosskopf, S., \& Lovell, C. A. K. (1997b). Biased technical change and the Malmquist productivity index. Scandinavian Journal of Economics, 99, 119-127.

Färe, R., \& Grosskopf, S. (1996). Intertemporal production frontiers: With dynamic DEA. Boston/London/Dordrecht: Kluwer.

Färe, R., Grosskopf, S., Lindgren, B., \& Roos, P. (1989). Productivity developments in Swedish hospitals: A Malmquist output index approach (Discussion Paper No. 89-3). Southern Illinois University.

Färe, R., Grosskopf, S., \& Lovell, C. A. K. (1992). Productivity change in Swedish pharmacies 1980-1989: A nonparametric Malmquist approach. Journal of Productivity Analysis, 3, 85-101.

Färe, R., Grosskopf, S., \& Norris, M. (1997a). Productivity growth, technical progress, and efficiency change in industrialized countries: Replies. American Economic Review, 87, 1040-1043.

Färe, R., Grosskopf, S., Norris, M., \& Zhang, Z. (1994). Productivity growth, technical progress, and efficiency change in industrialized countries. American Economic Review, 84, 66-83.

Griliches, Z. (1963). The sources of measured productivity growth: United States agriculture, 1940-1960. Journal of Politic Economy, 71(4), 331-346.

Grossman, G. M., \& Helpman, E. (1991). Innovation and growth in the global economy. MIT Press.

Gutierrez, L., \& Gutierrez, M. M. (2003). International R\&D spillovers and productivity growth in the agricultural sector: A panel cointegration approach. European Review of Agricultural Economics, 30, 281-303.

Hayami, Y. (1997). Development economics: From the poverty to the wealth of nations. Oxford: Clarendon Press.

Jamison, D., \& Lau, L. (1982). Farmer education and farm efficiency. Washington, DC: World Bank.

Johnson, D. K. N., \& Evenson, R. E. (1999). R\&D spillovers to agriculture: Measurement and application. Contemporary Economic Policy, $17,432-456$.

Keller, W. (2000). Do trade patterns and technology flows affect productivity growth? World Bank Economic Review, 14, 17-47.

Konings, J. (2001). The effects of foreign direct investment on domestic firms: Evidence from firm level panel data in emerging economies. Economics of Transition, $9,619-633$.

Lichtenberg, F. R. \& B. van Pottelsberghe de la Potterie. (1996). “International R\&D spillovers: a re-examination,” Working Paper No. 5668, National Bureau of Economic Research.

Lucas, R. E. (1988). On the mechanics of economic development. Journal of Monetary Economics, 22, 3-42.

Lucas, R. E. (1993). Making a miracle. Econometrica, 61, 251-272.

Lumenga-Neso, O., Olarrega, M., \& Schiff, M. (2001). On 'indirect' trade related RED spillovers (CEPR Discussion Paper 2871).

Mankiw, N. G., Romer, D., \& Weil, D. N. (1992). A contribution to the empirics of economic growth. Quarterly Journal of Economics, $107,407-437$.

Nehru, V., \& Dhareshwar, A. (1994). New estimates of total factor productivity growth for developing and industrial countries (World Bank Policy Research Working Paper, No. 1313).

Pardey, P. G., Roseboom, J., \& Fan, S. (1998). Trends in financing Asian and Australian agricultural research. In S. R. Tabor, W. Janssen, \& H. Bruneau (Eds.), Financing agricultural research: A sourcebook. The Hague: International Service for National Agricultural Research.

Park, W. G. (1995). International R\&D spillovers and OECD economic growth. Economic Inquiry, 33, 571-591.

Pray, C. E., \& Fuglie, K. O. (1998). Private investment in agricultural research and international technology transfer in Asia (Electronic Report from the Economic Research Service, No. 805).

Ray, S. C., \& Desli, E. (1997). Productivity growth, technical progress, and efficiency change in industrialized countries: Comment. American Economic Review, 87, 1033-1039.

Rivera-Batiz, L. A., \& Romer, P. M. (1991). Economic integration and endogenous growth. Quarterly Journal of Economics, 106, $531-555$.

Romer, P. (1986). Increasing returns and long run growth. Journal of Political Economy, 94, 1002-1037.

Romer, P. (1990). Endogenous technological change. Journal of Political Economy, 98, 71-102.

Sachs, J. D. (2001). Tropical underdevelopment (NBER Working Paper Series, No. 8119). 
Schimmelpfennig, D., \& Thirtle, C. (1999). The internationalization of agricultural technology: Patents, R\&D spillovers, and their effects on productivity in the European Union and United States. Contemporary Economic Policy, 17, 457-468.

Schultz, T. W. (1963). The economic value of education. New York, USA: Columbia University Press.

Thirtle, C., Lin, L., \& Piesse, J. (2003). The impact of research-led agricultural productivity growth on poverty reduction in Africa, Asia and Latin America. World Development, 31, 1959-1975.

Xu, B., \& Wang, J. (1999). Capital goods trade and R\&D spillovers in the OECD. Canadian Journal of Economics, 32, 1258-1274.

Zukowska-Gagelmann, K. (2002). Productivity spillovers from foreign direct investment in Poland. Economic Systems, 106, 407-473. 